\title{
Potential impacts of using sewage sludge biochar on the growth of plant forest seedlings
}

\section{Maria Isidoria Silva ${ }^{1}$ Cheryl Mackowiak ${ }^{2}$ Patrick Minogue $^{2}$ Alessandra Ferreira Reis $^{3}$ Ederlon Flavio da Veiga Moline ${ }^{2}$}

${ }^{1}$ Departamento de Engenharia Agronômica, Universidade Federal de Sergipe (UFS), Av. Marechal Rondon, Rosa Elze, 49100-000, São Cristovão, SE, Brasil. E-mail: mariaisisilva@gmail.com. Corresponding author.

${ }^{2}$ North Florida Research and Education Center, University of Florida, Quincy, FL, United States of America.

${ }^{3}$ Departamento de Engenharia Florestal, Universidade Federal de Sergipe (UFS), São Cristóvão, SE, Brasil.

ABSTRACT: Sewage sludge has long been successfully used in the production of nursery plants; however, some restriction may apply due to its high pathogenic characteristics. The process of charring the organic waste significantly reduces that undesired component and may be as effective as the non-charred residue. The aim of this study was to evaluate the effect of sewage sludge biochar on the growth and morphological traits of eucalyptus (Eucalyptus grandis L.) seedlings, and compare results with those observed when using uncharred sewage sludge. Treatments were arranged in a completely randomized design, in a 2 x 2 factorial scheme, with four replications. Charred and noncharred sewage sludge were tested with and without NPK addition. A control treatment was also evaluated. Ten weeks old eucalyptus seedlings were transferred to the pots and grew for eight weeks. Chlorophyll content, plant height and stem diameter were measured at 0,30 and 60 days after transplant. Shoot and root biomass were measured after plant harvest. Dickson Quality Index was calculated to evaluate the overall quality of seedlings. Biochar was effective in improving the seedlings quality, and had similar effects as the non-charred waste. Therefore, sewage sludge biochar has the potential to improve the process of production of forest species seedlings and further reduce the environmental risks associated with the use of non-charred sewage sludge.

Key words: Biosolids, pyrogenic carbon, environmental management.

Potenciais impactos do uso de biocarvão de lodo de esgoto no crescimento de mudas de especies florestais

RESUMO: O lodo de esgoto tem sido usado com sucesso há muito tempo na produção de mudas de espécies florestais em viveiro. Contudo, algumas restrições se aplicam devido às suas características patogênicas. O processo de carbonização desse resíduo orgânico reduz significativamente esse componente, resultando num material que pode ser tão efetivo quanto a matéria prima original. O objetivo do estudo foi avaliar o efeito do biocarvão de lodo de esgoto no crescimento e nos parâmetros morfológicos de mudas de eucalipto (Eucalyptus grandis L.), e comparar os resultados com aqueles observados para as mudas tratadas com lodo de esgoto. Os tratamentos foram distribuídos em delineamento inteiramente casualizado, em esquema fatorial $2 \times 2$, com quatro repetições. O lodo de esgoto, carbonizado e não carbonizado, foi testado com e sem a adição de adubação NPK. Um tratamento controle foi avaliado também. Mudas de eucalipto com 10 semanas foram transferidas para vasos contendo os tratamentos, onde cresceram por 60 dias. Teor de clorofila, altura da planta e diâmetro do coleto foram avaliados aos 0, 30 e 60 dias. A biomassa da parte aérea e da raiz foi avaliada após a colheita. O índice de qualidade de Dickson foi calculado para avaliar a qualidade geral das mudas. O biocarvão foi eficiente em melhorar a qualidade das mudas e seu efeito foi similar ao do lodo de esgoto. Portanto, esse biocarvão tem o potencial de melhorar o processo de produção de mudas de espécies florestais em viveiro, e pode ainda reduzir os riscos ambientais associados ao uso de lodo de esgoto.

Palavras-chave: biossólido, carbono pirogênico, manejo ambiental.

\section{INTRODUCTION}

Biosolids or sewage sludge is treated residuals from a wastewater treatment process. This production is increasing worldwide as a result of environmental protection policies that require mandatory wastewater treatment before returning it to the environment (LU et al., 2012). Although sludge corresponds to only $1 \%$ of the volume of the wastewater, the treatment and final disposal represents 20 to $60 \%$ of the operational costs (WEI et al., 2003), making land application an attractive option.

Sewage sludge, with a high carbon and nutrient content, can be used as a soil amendment to improve soil fertility and water holding characteristics. However, its application to soil may sometimes be risky because of the potential presence of pathogenic organisms and heavy metals (HE et al., 2010). Thermal treatment of sewage sludge through pyrolysis produces biochar, reducing volume and organic contaminant characteristics (LIU et al., 2014) 
and a greater proportion of $\mathrm{C}$ fixed in poly-condensed aromatic structures (KLEBER et al., 2015). The result is an increase in the half-life of the organic residues in soil (LEHMANN et al., 2015). However, there is little information about the agronomic properties of biochars derived from sewage sludge.

Recent studies have reported the use of sewage sludge biochar in soil (HOSSAIN et al., 2011; LIU et al., 2014). However, few have compared the effect of sewage sludge versus sewage sludge biochar on plant growth. So far, there is no record of the effect of sewage sludge biochar on the growth of tree species, such as eucalyptus seedlings. Obtaining high quality seedlings is critical for the successful establishment of a good plantation stand (BINOTTO et al., 2010), and this is directly related to the seedlings growing medium. Recycling of a nutrient-rich waste into a safe and effective fertilizer to support sustainable agriculture is an overriding goal of this research.

The objective of this study was to evaluate the suitability of using sewage sludge biochar to grow eucalyptus seedlings in a greenhouse condition, and compare the result with those of plants treated with sewage sludge.

\section{MATERIALS AND METHODS}

\section{Sewage sludge collection and biochar production}

Sewage sludge (Class B) was collected from a drying bed, at a municipal wastewater treatment facility (WWTF), located in Tallahassee, Florida, U.S.A, where wastewater is treated through an activated sludge treatment process. Sewage sludge had $91 \pm 2 \%$ moisture and $6.8 \pm 0.3$ $\mathrm{pH}$ units (mean \pm std), containing the following total elemental composition: $5.7 \pm 0.9 \%$. N, $1.3 \pm 0.5 \% \mathrm{P}, 0.2 \pm 0.1 \% \mathrm{~K}, 94.0 \pm 21.3 \mathrm{mg} \mathrm{kg}^{-1} \mathrm{Cu}$, $88.8 \pm 21.0 \mathrm{mg} \mathrm{kg}^{-1} \mathrm{Zn}, 18 \pm 3 \mathrm{mg} \mathrm{kg}^{-1} \mathrm{Mo}, 4.0 \pm 0.8 \mathrm{mg}$ $\mathrm{kg}^{-1} \mathrm{As}, 0.80 \pm 0.26 \mathrm{mg} \mathrm{kg}^{-1} \mathrm{Cd}, 20 \pm 9 \mathrm{mg} \mathrm{kg}^{-1} \mathrm{~Pb}$, and $3.6 \pm 0.6 \mathrm{mg} \mathrm{kg}^{-1} \mathrm{Ni}$.

Biochar was produced in a modified custom designed Top-lit Updraft retort kiln, which is a micro-kiln that uses a reburner to eliminate volatile by-products of pyrolization (NSAMBA et al., 2015). Both, particulates, as well as the non-condensable gases, are combusted to provide heat for driving the pyrolysis reaction. Sewage sludge was dried in an oven at $45^{\circ} \mathrm{C}$ for 5 days and subsequently $20 \mathrm{~kg}$ of the feedstock was pyrolyzed over 3 hours, at approximately 450 $650^{\circ} \mathrm{C}$, based upon thermal gun measurements. Biochar characteristics were: $25.6 \%$ ash, $54.2 \%$ volatile matter, $20.2 \%$ fixed $\mathrm{C}, 45.5 \% \mathrm{C}, 7.43 \%$
$\mathrm{N}, 4.85 \% \mathrm{H}, 1.14 \% \mathrm{~S}, 15.5 \%$ O. Biochar $\mathrm{pH}=7.5$ and $\mathrm{EC}=7.29$.

\section{Soil collection and experimental set up}

Soil used in this experiment was collected from a fallow field at North Florida Research and Education Center (NFREC), Quincy, Florida. The soil was air-dried and sieved to pass through a $2 \mathrm{~mm}$ screen. Soil was classified as Loamy, kaolinitic, thermic Grossarenic Kandiudults (Soil Survey Staff, 2014), with $\mathrm{pH}$ (ratio of 1:5 w/v) of 5.8.

The pot experiment was arranged in a completely randomized design with six treatments: 1) Control soil without biochar and without NPK fertilization; 2) Control soil without biochar and with NPK fertilization; 3) Biochar at a rate of $40 \mathrm{t}$ ha $^{-1}$ without NPK fertilization; 4) Biochar at a rate of $40 \mathrm{tha}^{-1}$ with NPK; 5) Sewage sludge at a rate of 40t ha ${ }^{-1}$ without NPK fertilization; and 6) Sewage sludge at a rate of $40 \mathrm{tha}^{-1}$ with NPK fertilization). A known weight $(3.0 \mathrm{~kg})$ of air-dried and sieved $(2 \mathrm{~mm})$ soil was put into plastic bags and thoroughly mixed with the appropriate rate of biochar or sewage sludge, then transferred into plastic pot. After a one-week incubation period at field capacity, 10-week-old, eucalyptus (Eucalyptus grandis L.) seedlings were transferred to each pot and maintained at $80 \%$ field capacity during the experiment.

Chlorophyll content of the mid-section, fully expanded leaves, was measured, using a handheld chlorophyll meter (SPAD-502, Konica Sensing, Inc., Osaka, Japan). Stem diameter was measured at $2 \mathrm{~cm}$ above the soil surface, using a digital caliper. The measurements were taken at 0 (T1), 30 (T2) and 60 (T3) days after transplanting (DAT). Plants were allowed to grow for 60 days. Plants were then harvested and separated into roots and shoots. Plant tissues were washed thoroughly with tap water, followed by rinsing with deionized water. Shoots and roots were oven-dried for 3 days at $65^{\circ} \mathrm{C}$ and weighed. Dickson Quality Index (DQI) was calculated to evaluate seedling quality as a function of total dry matter (TDM), shoot height (SH), stem base diameter (SBD), shoot dry matter (SDM) and root dry matter (RDM), and is given as follows (eq 1) (DICKSON et al., 1960):

$1 Q D=\frac{T D M(g)}{\frac{S H(\mathrm{~cm})}{S B D(\mathrm{~cm})}+\frac{S D M(\mathrm{~g})}{R D M(\mathrm{~g})}}$

(eq 1).

\section{Statistical analyses}

Results are reported as the means of four replicates. One and two-way analyses of variance 
(ANOVA) were conducted to test the significance of the treatments using SISVAR software package (FERREIRA, 2011). Treatment means were separated using Tukey's multiple range test at $P<.05$.

\section{RESULTS AND DISCUSSION}

Thirty days after the plants were transferred to the treatment pots (T2), the chlorophyll content in the fertilized pots were similar for SS and SSB treatments, increasing 35 and $47 \%$, respectively, as compared with the control with fertilizer. In the absence of fertilizer, the chlorophyll content was $\mathrm{SSB}>\mathrm{SS}>$ control (Figure 1). However, after 60 days (T3), results were $\mathrm{SSB}>\mathrm{SS}=$ control. Absence of additional N-P-K fertilizer was most noticeable in the chlorophyll measurements with the control treatment. Overall, plants had the highest chlorophyll content at T2, except in the control. This is probably related to the higher bioavailability of $\mathrm{N}$ during the first month (FIGUEREDO et al., 2014). Most of the leaf nitrogen content is incorporated into the chlorophyll; therefore, this pigment gives an indirect estimation of the nitrogen content of the plant leaves (PETERSON et al., 2010). Sewage sludge- and manure-derived biochars have the potential to be used both, as soil fertilizer and conditioner (CHAN et al., 2008). According to LU et al. (2012), biosolids release nutrients to the plants at a slower rate over a longer period of time with higher use efficiency, when compared to mineral

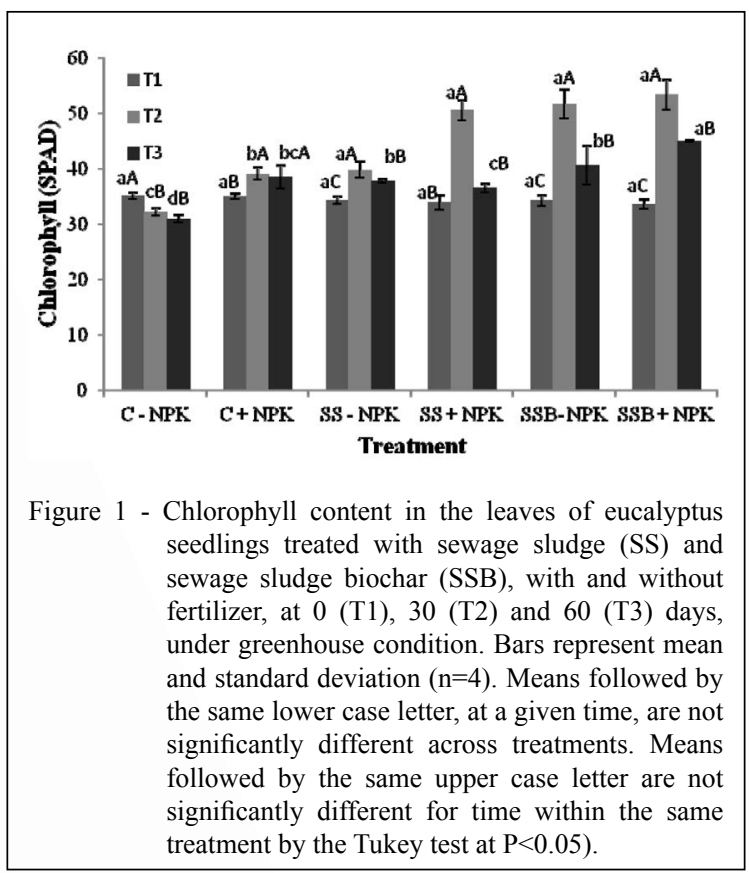

fertilizers. This is because the primary nutrients in biosolids are in organic forms and rely on biological mineralization to become available.

Determining plant height is important for estimating the initial growth, as well as the quality of tree seedlings in the field. In our study, plant height did not differ much at $\mathrm{T} 2$ for the treatments with fertilizer addition (Figure 2), except for the SS which was $11 \%$ higher than the control. The same pattern was observed in the absence of fertilizer. Fertilizer did not influence the plant height in the biochar or sewage sludge treatments. At T3, regardless of the presence of fertilizer, SSB and SS treatments showed 19\% improvement in plant height as compared with the control. There was no significant difference between SS and SSB treatments. Plant height increased with time in all treatments, an average of $27 \%$ (T1 to T2) and $80 \%$ (T1 to T3) for the control and, 32\% (T1 to $\mathrm{T} 2$ ) and $94 \%$ (T1 to T3) for the organic amendments.

Of the fertilized plants at T2, stem diameter was $\mathrm{SSB}=$ control $>\mathrm{SS}$ (Figure 3 ), and of the unfertilized plants SSB $>$ SS $=$ control. Fertilizer addition did not have any influence on the stem diameter in the organic treatments, but it showed a significant increase in the control treatment. At T3, regardless of the presence of fertilizer, the organic amendments responded similarly, with stem diameter greater than the control. Stem diameter is used to estimate the quality of the seedlings and it is often related to the capacity for new root development, an important parameter for tree seedling field establishment (BINOTTO et al., 2010).

Plant shoot dry mass did not significantly differ among the organic amendments, with or

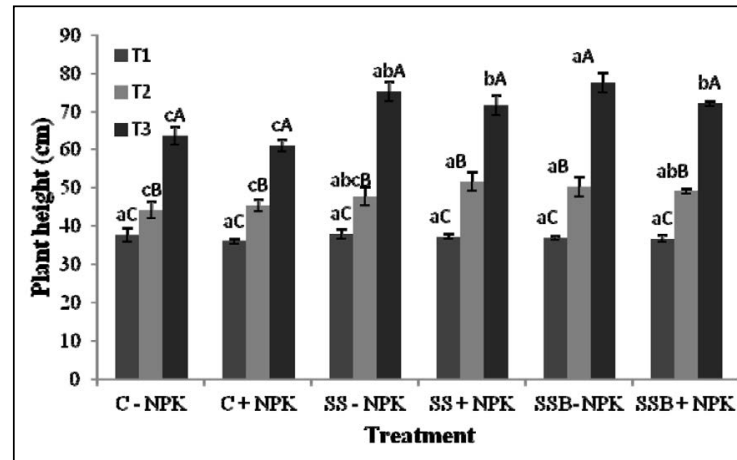

Figure 2 - Height of eucalyptus seedlings treated with sewage sludge (SS) and sewage sludge biochar (SSB), with and without fertilizer, at 0 (T1), 30 (T2) and 60 (T3) days, under greenhouse condition. (Results are mean and $\mathrm{SD}, \mathrm{n}=4$. Means followed by the same lower case letter, at a given time, are not significantly different. Means followed by the same upper case letter are not significantly different within the same treatment by the Tukey test at $\mathrm{P}<0.05$ ). 


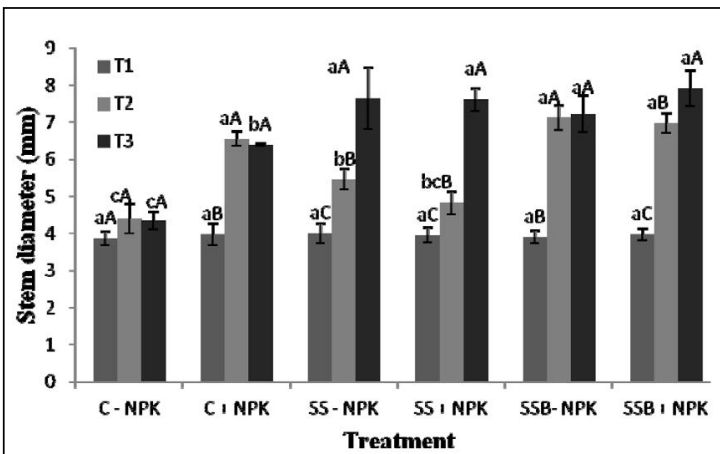

Figure 3 - Stem diameter of eucalyptus seedlings treated with sewage sludge (SS) and sewage sludge biochar (SSB), with and without fertilizer, at 0 (T1), 30 (T2) and 60 (T3) days, under greenhouse condition. (Results are mean and SD, $n=4$. Means followed by the same lower case letter, at a given time, are not significantly different. Means followed by the same upper case letter are not significantly different within the same treatment by the Tukey test at $\mathrm{P}<0.05$ ).

without fertilizer (Figure 4). Pooling the organic amendment treated pots, their shoot mass was $58 \%$ and $500 \%$ greater than the control with or without fertilizer, respectively. Interestingly, the SSB without fertilizer had 2.3-fold greater root dry mass, compared to the other treatments. It seems that the absence of fertilizer somehow stimulated root growth in the biochar treated soil. Given the importance of the root system development in forestry seedlings, the use of SSB may become a promising strategy. However, further work is needed to determine the cause of the effect demonstrated in this experiment.

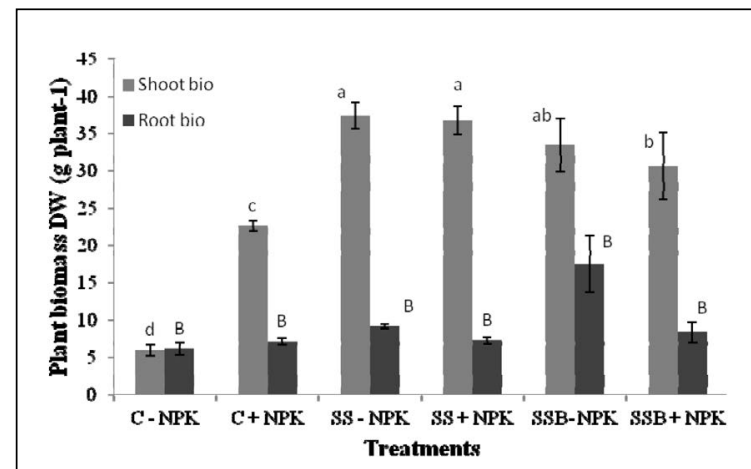

Figure 4 - Shoot and root biomass dry weight of eucalyptus seedlings treated with sewage sludge (SS) and sewage sludge biochar (SSB), with and without fertilizer, under greenhouse condition. (Results are mean and $\mathrm{SD}, \mathrm{n}=4$. Means followed by the same lower case letter or upper case letter are not significantly different by the Tukey test at $\mathrm{P}<0.05$ ).
Overall, trees in all treatments allocated more energy into growing shoot than root. The organic amended treatments produced 4-fold more shoot than roots. However, SSB without fertilizer resulted in the lowest shoot: root ratio among the organic treatments, as a result of the outstanding root development. High nutrient availability can end up limiting the need for root expansion in soil (MARSCHNER, 2011). However, under times of water stress (drought conditions) a lower shoot: root ratio may result in greater exploitation of the soil volume.

Even though several variables can be used to evaluate seedling quality, such as height, stem diameter, shoot and root biomass, integration of some morphological traits via the Dickson Quality Index becomes a strategy to avoid the risk of selecting taller, yet weaker seedlings (JOHNSON and CLINE, 1991). The index takes in consideration important ratios that measure the robustness $(\mathrm{SH} / \mathrm{SBD})$ and biomass balance distribution (SDM/RDM), and varies from 0 to 1 . The higher this value the better the quality of the seedling (CALDEIRA et al., 2005). In this study, Dickson Quality Index varied from 0.08 to 0.46 (Figure 5). There were no significant differences among the organic amended treatments, but ratings were 47 and $450 \%$ greater than the control, with or without fertilizer, respectively, confirming the beneficial effects of the sewage sludge and sewage sludge biochar for the growth of eucalyptus seedlings. The DQI was a good indicator of seedling quality, robustness, and biomass distribution.

One of the concerns in this study was the viability of the sewage sludge biochar as far as its

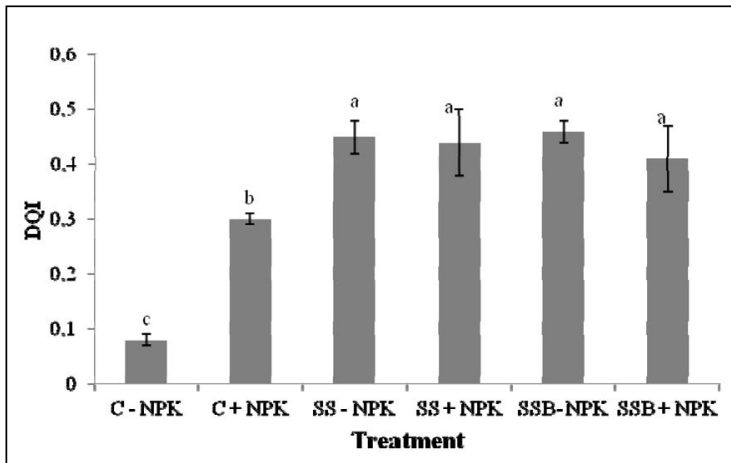

Figure 5 - Dickson Quality Index (DQI) of eucalyptus seedlings treated with sewage sludge (SS) and sewage sludge biochar (SSB), with and without fertilizer, under greenhouse condition. (Results are mean and SD, $n=4)$. Means followed by the same lower case letter or upper case letter are not significantly different by the Tukey test at $\mathrm{P}<0.05$ ). 
agronomic value is concerned. This is because the density and chemical composition of the sewage sludge, as well as the relatively low process temperature, can negatively influence the pyrolysis process, leading to an incomplete carbonization and producing a biochar with high volatile matter content and labile $\mathrm{C}$. The exposure of eucalyptus seedlings to this type of biochar product might induce toxicity symptoms, due to the remaining volatile organics, which was indeed observed in the first week after transplanting the seedlings to the treatment pots. However, the negative plant response ceased over time (2 to 4 weeks). Furthermore, results of the chlorophyll content of the seedlings treated with biochar were even better than those of the ones treated with sewage sludge at $\mathrm{T} 2$ and $\mathrm{T} 3$.

\section{CONCLUSION}

Use of sewage sludge biochar as a soil amendment for the growth of eucalyptus seedlings has proven feasible, as it improved the quality of the seedlings, per the Dickson Quality Index. Even though there was no significant difference between sewage sludge and sewage sludge biochar for the measured parameters, application of sewage sludge biochar is preferred and has advantages, due to a greater degree of recalcitrant carbon and the absence of pathogenic organisms via the pyrolysis process. However, before soil application or use in nursery container production, sewage sludge biochar may require a short washing, incubation, or other weathering process to remove volatile organic compounds.

\section{ACKNOWLEDGEMENTS}

We thank CAPES for the pos-doctoral grant making possible the development of this study. We also thank University of Florida (NFREC) for supporting our research.

\section{REFERENCES}

BINOTTO, A.F. et al. Correlations between growth variables and the Dickson Quality Index in forest seedlings. Cerne, Lavras, v.16, n.4, p.457-464, oct./dec. 2010. Available from: <http://dx.doi. org/10.1590/S0104-77602010000400005>

CALDEIRA, M.V.W. et al. Effect of different doses of vermicompost on the growth of Apuleia leiocarpa (Vog) Macbr. seedlings. Revista Acadêmica: Ciências Agrárias e Ambientais, Curitiba, v.3, n.2, p.11-17, abr./jun. 2005. Available from: $<$ http:// www.scielo.br/scielo.php?script $=$ sci nlinks\&ref $=000112>$.

CHAN, K.Y. et al. Using poultry litter biochars as soil amendments. Australian Journal of Soil Research. v.46, n.5, p.437-444, ago. 2008. Available from: <http://dx.doi.org/10.1071/SR08036>.
DICKSON, A. et al. Quality appraisal of white spruce and white pine seedling stock in nurseries. Forest Chronicle, v.36, n.1, p.1013,1960 .

FERREIRA, D.F. Sisvar: a computer statistical analysis system. Ciência e Agrotecnologia, Lavras, v.35, n.6, p.1039-1042, nov./ dez. 2011. Available from: <http://dx.doi.org/10.1590/S1413$70542011000600001>$.

FIGUEREDO, C.S. et al. Addition of rice hulls in different substrates to Eucalyptus globulus seedlings production. Journal of Biotechnology and Biodiversity, Tocantins, v.5, n.1, p.71-78, fev. 2014. Available em: <http://revista.uft.edu.br/index.php/JBB/ article/view/73>

HE, Y.D. et al. The fate of $\mathrm{Cu}, \mathrm{Zn}, \mathrm{Pb}$ and $\mathrm{Cd}$ during the pyrolysis of sewage sludge at different temperatures. Environmental Technology, London, v.31, n.5, p.567-574, mar. 2010. Available from: <http://dx.doi.org/10.1080/09593330903514466>.

HOSSAIN, M.K. et al. Agronomic properties of wastewater sludge biochar and bioavailability of metals in production of cherry tomato (Lycopersicon esculentum). Chemosphere, Amsterdam, v.78, n.9, p.1167-1171, fev.2010. Available from: <http://dx.doi. org/10.1016/j.chemosphere.2010.01.009>

JOHNSON, J.D.; CLINE, M.L. Seedling quality of southern pines. In: DURYEA, M.L.; DOUGHERTY, P.M. (Eds.). Forest regeneration manual. Netherlands: Klumer Academic, 1991. p.143-162.

KLEBER, M. et al. Characteristics of biochar: macro-molecular properties. In: LEHMANN, J.; JOSEPH, S. Biochar for environmental management: science and technology. 2. ed., New York, Earthscan, 2015. 928p.

LEHMANN, J. et al. Persistence of biochar in soil. In: LEHMANN, J.; JOSEPH, S. Biochar for environmental management: science and technology. 2.ed. New York: Earthscan, 2015. 928p.

LIU, T. et al. Nutrients and heavy metals in biochar produced by sewage sludge pyrolysis: its application in soil amendment. Polonian Journal of Environmental Studies, Poland, v.23, n.1, p.271-275, nov.2014. Available from: <http://www.pjoes.com/ pdf/23.1/Pol.J.Environ.Stud.Vol.23.No.1.271-275.pdf>.

LU, Q. et al. Land application of biosolids in the USA: a review. Applied and Environmental Soil Science, v.2012. p.1-11, 2012. Available from: <http://dx.doi.org/10.1155/2012/201462>.

MARSCHNER H. Mineral nutrition of higher plants. 3.ed. New York: Academic, 2011. 672p.

NSAMBA, H. et al. Designing and performance evaluation of biochar production in a top-lit updraft up-scaled gasifier. Journal of Sustainable Bioenergy Systems, v.5, n.2, p.41-55, jun. 2015.

PETERSON, T.A. et al. Using a chlorophyll meter to improve nitrogen management. G93-1171-A USDA-ARS. Lincoln, Spectrum Technologies, 2010. 7p. Available from: <http:// digitalcommons.unl.edu/cgi/viewcontent.cgi?article $=2349 \&$ conte $\mathrm{xt}=$ extensionhist $>$.

SOIL SURVEY STAFF. Keys to Soil Taxonomy. 12. ed. Soil Survey Laboratory. National Soil Survey Center. USDA-NRCS, Washington, DC, 2014. 372p. 